\begin{tabular}{|c|c|c|c|c|c|c|}
\hline \multirow{4}{*}{ Impact Factor: } & ISRA (India) & $=3.117$ & SIS (USA) & $=0.912$ & ICV (Poland) & $=6.630$ \\
\hline & ISI (Dubai, UAE & $=0.829$ & РИНЦ (Russia & $=\mathbf{0 . 1 5 6}$ & PIF (India) & $=1.940$ \\
\hline & GIF (Australia) & $=0.564$ & ESJI (KZ) & $=8.716$ & IBI (India) & $=4.260$ \\
\hline & JIF & $=1.500$ & SJIF (Morocco & $=\mathbf{5 . 6 6 7}$ & OAJI (USA) & $=0.350$ \\
\hline
\end{tabular}

\section{SOI: 1.1/TAS DOI: 10.15863/TAS International Scientific Journal Theoretical \& Applied Science}

p-ISSN: 2308-4944 (print) e-ISSN: 2409-0085 (online)

Year: $2019 \quad$ Issue: $04 \quad$ Volume: 72

Published: $30.04 .2019 \quad$ http://T-Science.org
QR - Issue

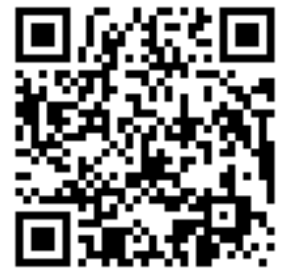

QR - Article

Erkin Erkamovich Rustamov

Ministry of Economy and Industry,

Head of the Department of the demography, improvement of the human capital quality and level erustamov@mineconomy.uz $+998977412484$

\title{
THE WAYS OF TRAINING HIGH QUALIFIED PERSONNEL FOR AN INNOVATION ECONOMY
}

Abstract: The article analyzes the development of personnel training in higher education, taking into account the needs, potential and resources of the economic sectors. The main directions of reforming high qualified personnel training system for innovation economy have been analyzed.

In order to develop job creative ethics of personnel, it was suggested to increase the number of students in higher education and adopt the STEM system of education in accordance with the international experience.

Key words: High qualified personnel, Creative worker, STEM system.

Language: English

Citation: Rustamov, E. E. (2019). The ways of training high qualified personnel for an innovation economy. ISJ Theoretical \& Applied Science, 04 (72), 34-39.

Soi: http://s-o-i.org/1.1/TAS-04-72-6 Doi: crossef https://dx.doi.org/10.15863/TAS.2019.04.72.6

\section{Introduction.}

Creation of highly productive working places on account of the modernization and technological reequipment of enterprises through innovative economic development of the country, does not fully meet current requirements. This creates serious problems in the labor market in terms of ensuring the employment of young people - graduates of educational institutions.

Therefore, the President of the Republic of Uzbekistan "Today we are on the path of innovative development, aimed at radical renewal of all spheres of state and society. Innovation is a future. We must start with the innovative ideas, innovative approach, if we are to begin building our great future" ${ }^{1}$

Accordingly, the strategy of innovative development of the Republic of Uzbekistan for 20192021 was developed ${ }^{2}$. The main objective of the strategy was to develop human capital as a key factor determining the competitiveness and innovative development level of the country on the international arena. In addition, the strategy focuses on the creation of highly productive workplaces, thus creating a basis for the employment of the population.

Above stated strategy analyzes the improvement of the education and training system in higher education in accordance with the demand, capacities and resources of economic sectors. The main directions for reforming the education system of training highly qualified personnel for the innovation economy have been clarified. Indicators of creative workers and the advantages of staff training on the basis of the STEM - education system was demonstrated.

\section{Body part.}

The level of education of the population is assessed from the point of view of the individual, state and society, which influences the formation of the spiritual and intellectual needs and abilities of a person. At a personal level, it is the ability to fully demonstrate one's self-esteem and develop intellectual abilities. At the state level, education has become the most important component of economic development and the accumulation of national wealth. At

\footnotetext{
${ }^{1}$ The appeal of the President of the Republic of Uzbekistan, Shavkat Mirziyoev to the Oliy Majlis on December 23, 2017 www.prezident.uz
}

\footnotetext{
2 Presidential Decree Of The Republic Of Uzbekistan of September 21, 2018 No. UP-5544 "About approval of Strategy of innovative development of the Republic of Uzbekistan for 2019-2021" www.lex.uz
} 


\begin{tabular}{|c|c|c|c|c|c|c|}
\hline \multirow{4}{*}{ Impact Factor: } & ISRA (India) & $=3.117$ & SIS (USA) & $=0.912$ & ICV (Poland) & $=6.630$ \\
\hline & ISI (Dubai, UAE & $=0.829$ & РИНЦ (Russia & $=\mathbf{0 . 1 5 6}$ & PIF (India) & $=1.940$ \\
\hline & GIF (Australia) & $=0.564$ & ESJI (KZ) & $=8.716$ & IBI (India) & $=4.260$ \\
\hline & JIF & $=1.500$ & SJIF (Morocco & $=5.667$ & OAJI (USA) & $=0.350$ \\
\hline
\end{tabular}

community level education is the basis of social development.

Therefore, according to the Presidential Decree of July 27, 2017 № UP-3451 "On Measures for Further Expansion of Participation of the Spheres and Industries in the Spheres of Improving the Training of Higher Education Professionals" training the highly qualified specialists that meet modern standards and the demand for the specialities is formed in line with the needs of sectors and industries of the economy, the training programs of higher education are formed in accordance with the production, technical and technological relations of the enterprises and prospective development programs of the Republic of Uzbekistan.

The imbalance between the number of highly qualified personnel that was quoted and the need for them in the country has led to a sharp contrast between demand and supply in the labor market. For example, during the period of 3 years from 2014 to 2016, the number specialists in the sphere of information and communication technologies was less than required in the economy by around 100-1400. Only in 2017 this difference was reduced till 800 (table 1 ).

Table 1. Training high qualified specialists in the sphere of ICT.

\begin{tabular}{|c|c|c|c|c|c|}
\hline Index & $\mathbf{2 0 1 3}$ & $\mathbf{2 0 1 4}$ & $\mathbf{2 0 1 5}$ & $\mathbf{2 0 1 6}$ & $\mathbf{2 0 1 7}$ \\
\hline Number of specialists (thousands of people) & 3,4 & 3,8 & 4,1 & 4,2 & 4,8 \\
\hline $\begin{array}{c}\text { Demand for the specialists (thousands of } \\
\text { people) }\end{array}$ & 4,1 & 4,8 & 5,4 & 5,6 & 5,6 \\
\hline
\end{tabular}

Source: Ministry of Economy and Industry of the Republic of Uzbekistan

In the session held by The President of the Republic of Uzbekistan on October 24, 2018 which was dedicated to the issues of further development of higher education, the quality of training, expansion of science and production integration, Shavkat Mirziyoyev said "It is a pity that in the midst of a rapidly developing economy of the country the higher education system was one of the locomotives of the development. It is a bitter truth that there is not any system that meets the structural changes of the labor market, training young people for the vocational and entrepreneurial skills"3.

Therefore, Ministry of Higher and Secondary Special Education and Ministry of Employment and Labor Relations have been tasked with forecasting the demand for specialities of the real sector of the economy for at least 10 to 15 years and taking appropriate measures ${ }^{4}$.
The classics of economic theory argue that the basis of achieving economic growth is dependent on natural resources, current labor, interest rates, or purchasing power of the national currency. However, the American economist, M. Porter (Harvard Business School) in his scientific work maintains a new concept - the main factor leading to growth - the state's competitiveness.

M.Porter has rightly asked why despite of the insufficient natural resources of Germany, Japan, Switzerland, Italy and South Korea stated high economic rates. Besides, Germany, Switzerland and Sweden they have the highest rates of economic growth despite the lack of labor force. In his opinion, the competitiveness of each country depends on its ability to innovate and modernize the national economy. Therefore, the main factor of competitiveness at the national level is the level of labor productivity ${ }^{5}$.

\footnotetext{
${ }^{3}$ Need for modern skills for a rapidly developing economy // UzA, October 24, 2018

${ }^{4}$ The speech of the President of the Republic of Uzbekistan at the solemn ceremony dedicated to the 26th anniversary of the adoption of the Constitution, www.prezident.uz
}

5 Porter M. E. Competitive Strategy: Techniques for Analyzing Industries and Competitors (2nd ed.) - New York: Free Press, 1998. - 397 p. 


\begin{tabular}{|c|c|c|c|c|c|c|}
\hline \multirow{4}{*}{ Impact Factor: } & ISRA (India) & $=3.117$ & SIS (USA) & $=0.912$ & ICV (Poland) & $=6.630$ \\
\hline & ISI (Dubai, UAE & $=0.829$ & РИНЦ (Russia & $=\mathbf{0 . 1 5 6}$ & PIF (India) & $=1.940$ \\
\hline & GIF (Australia) & $=0.564$ & ESJI (KZ) & $=8.716$ & IBI (India) & $=4.260$ \\
\hline & JIF & $=1.500$ & SJIF (Morocco & $=5.667$ & OAJI (USA) & $=0.350$ \\
\hline
\end{tabular}

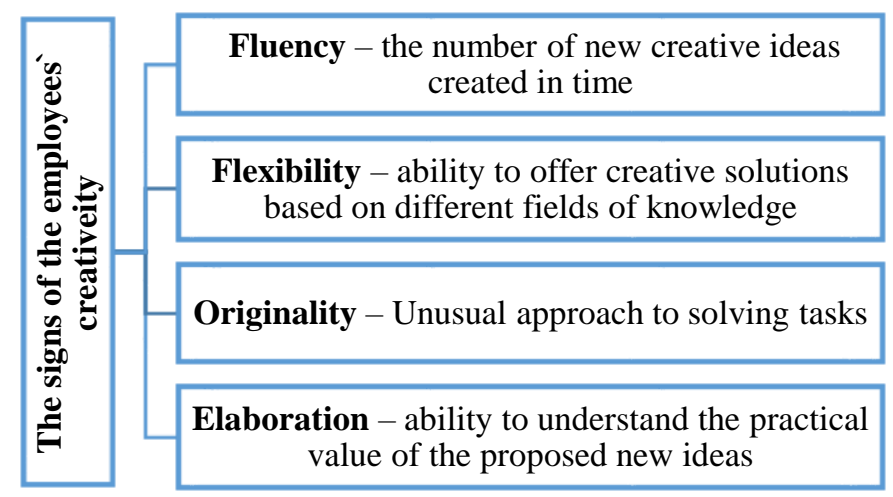

Figure 1. The signs of the employee`s creativeity ${ }^{6}$

Sustainable improvement of productivity in innovative development conditions, first of all, depends on modern knowledge and creativity of employees. Creativity (Latin, "creatio" - from the word "creation") is the ability of employees to create radically new ideas and creative decisions making. American psychologist Joy Paul Gilford has clarified four signs of creativity (figure 1).

The higher education system plays an essential role in shaping the creativity potential of the personnel. For example, training entrepreneurs, who are able to integrate innovations into production and market, is oneof the most important directions of US universities. Training of innovative entrepreneurs is different from the preparation of scholars or professionals. Business-schools, entrepreneurship centers, engineering and applied sciences departments have been set up to reveal the essence of the process of transforming the scientific and technological developments into social benefit within the framework of universities for the preparation of innovative staffs?

In the World Bank President Jim Yon Kim's article titled "How to Promote Human Capital Level Development or Government's Investing in human capital", published by the US-based magazine, points out that in countries with low human capital, currently the productivity of the human capital that have a good quality education and more productive health care is higher than those whose human capital is less developed by $30-50$.

Over recent years, the number of new national and international higher education institutions (including branches) operating in our country reached 98. As the head of our government mentioned "The percentage of the graduates of secondary speciali zed educational institutions who pursued further higher education was 9 to $10 \%$ in Uzbekistan. Thanks to the measures taken over the past two years, we have managed to increase this figure was increased over the 15 percent. But that is not enough. If we look at the experience of developed countries in the world, it is 60-70 percent. Therefore, it is our task to raise the level of enrollment of higher education graduates in our country till $20 \%$ in 2019 and continue increasing them in the coming years".

The figure 2 provides information about the opportunities of having higher education for youth in different countries These indicators are comparable to the UNESCO's "Gross Entry Ratio to First Tertiary Programs 2015" (where the percentage coverage of adolescents with appropriate education, in \%), reflecting differences among countries and percentage of Uzbekistan is 6 times less than other others (figure 2).

\footnotetext{
${ }^{6}$ Gilford Dj. Structural model is intellectually. Psychology myshleniya. - M., 1965. - 244 h.

${ }^{7}$ Gildons M. Engineering by the numbers. Washington, DC: American Society for Engineering Edication, 2008. -P.63-67. 


\begin{tabular}{|c|c|c|c|c|c|c|}
\hline \multirow{4}{*}{ Impact Factor: } & ISRA (India) & $=3.117$ & SIS (USA) & $=0.912$ & ICV (Poland) & $=6.630$ \\
\hline & ISI (Dubai, UAE & $=0.829$ & РИНЦ (Russia & $=0.156$ & PIF (India) & $=1.940$ \\
\hline & GIF (Australia) & $=0.564$ & ESJI (KZ) & $=8.716$ & IBI (India) & $=4.260$ \\
\hline & JIF & $=1.500$ & SJIF (Morocce & $=5.667$ & OAJI (USA) & $=0.350$ \\
\hline
\end{tabular}

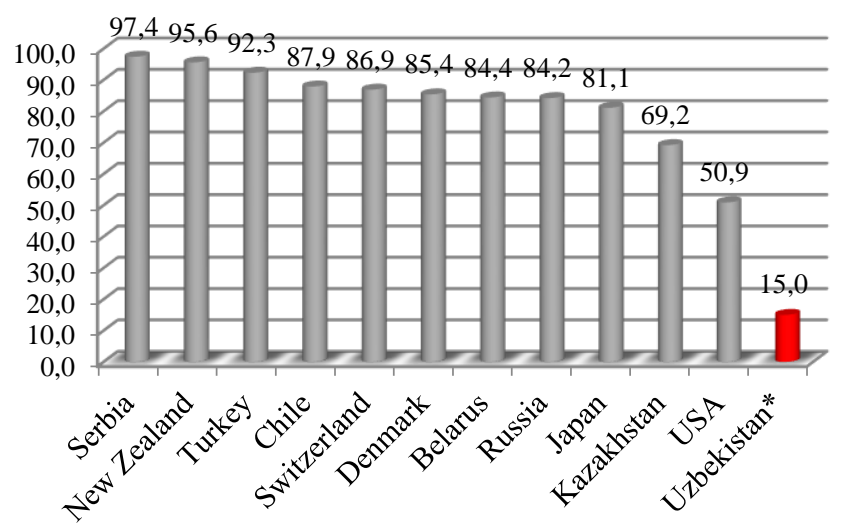

Figure 2. The percentage of applicants who entered to the higher education institutions with overall ${ }^{8}$

Strategy of innovation development of the Republic of Uzbekistan in 2019-2021 was adopted in order to ensure dynamic development of the country on the basis of innovative ideas, developments and technologies. The Strategy of Uzbekistan is to enter into the top 50 most developed countries in the world by 2030 accordingly with the Global Innovation Index. It is also envisaged to improve the quality and coverage of education at all levels, to develop a continuous education system, and to ensure the flexibility of the staff training system in order to meet the needs of the economy ${ }^{9}$.

Meanwhile, the analysis revealed that as a result of the lack of integration of the theory and practice at the higher education system of the country, the lack of the interrelations between the higher education science - production and the inadequate organization of qualification practices, most graduates could not become specialists which will require further training. The prestige of higher education institutions and the academic potential of professors and teachers still do not have a decent place in the international scientific community. There are no conditions for the development of science at the higher educational institutions, integration with research, the effectiveness of scientific activities and the ability of gifted students to pursue scientific researches, as well as the introduction of innovative techniques in the educational process.

Therefore, on the base of the country's strategy of innovative development, the following trend reforms at the higher education system identified:

increasing the coverage of the population with higher education;

Establishment of new higher educational institutions, including branches of foreign higher educational institutions; gradual abolition of admission limits for higher education institutions;

making an open access for applicants to enter several higher education institutions at once;

increase the share of students in in the sphere of natural and technical subjects;

development and implementation of the national quality assurance system for the education system and its impact on the country's innovative development;

development of STEM education system in the country;

establishment of forwarding centers in leading higher education institutions.

Therefore, foreign specialists are being involved in the teaching process of the higher education institutions and the measures of organizing the classes with the modern literature that is used in developed countries, have been taken. Advanced training courses of perspective scientific and pedagogical personnel (first of all, in engineering, technical and architectural education) are available.

Only in 2018, 13 new universities, including the Ipak Yuli International Tourism University, the branch of the National University of Technology Research in Almalyk city, Puchon and Adju universities of South Korea started their work in Tashkent. According to the results of the UzbekRussian Education Forum, which was held in Tashkent for the first time in 2018, 114 contracts and agreements on educational and scientific activity were signed, which envisages the organization of 6 branches of the prestigious higher educational institutions of Russia including 52 joint educational programs and 2 faculties in Uzbekistan.

At the Tashkent State Economic University in cooperation with the Austrian IMC University Krems, The Faculty of International Economic Relations was established. For the first time,

\footnotetext{
${ }^{8}$ UNESCO indicator - Gross Entry Ratio to First Tertiary Programs, 2015 // uis.unesco.org/index *) The level of enrollment of tertiary education institutions graduates with higher education.

${ }^{9}$ The Decree of the President of the Republic of Uzbekistan dated 21.09.2018. No. UP-5544 Approval of the Strategy for Innovative Development of the Republic of Uzbekistan for 2019-2021" www.lex.uz 


\begin{tabular}{|c|c|c|c|c|c|c|}
\hline \multirow{4}{*}{ Impact Factor: } & ISRA (India) & $=3.117$ & SIS (USA) & $=0.912$ & ICV (Poland) & $=6.630$ \\
\hline & ISI (Dubai, UAE & $=0.829$ & РИНЦ (Russia & $=\mathbf{0 . 1 5 6}$ & PIF (India) & $=1.940$ \\
\hline & GIF (Australia) & $=0.564$ & ESJI (KZ) & $=8.716$ & IBI (India) & $=4.260$ \\
\hline & JIF & $=1.500$ & SJIF (Morocco & $=5.667$ & OAJI (USA) & $=0.350$ \\
\hline
\end{tabular}

100 bachelors are trained on the department of "export-oriented management" and "tourism and hotel management", which today are extremely competitive in the labor market.

Training of creative students for the modern innovation economy requires a radical renewal of teaching methods at higher education. Nowadays, most higher education institutions are using traditional reproductive methods of teaching. Especially, in many countries of the world STEM (S - science (natural sciences); $\mathrm{T}$ - technology (technologies); E engineering; $M$ - mathematics system software has been introduced. In particular, in the US in 2013 a strategic plan for the development of STEM education was adopted. According to this plan, it is planned to increase the share of employees receiving STEM education by $16 \%$ by 2024 . According to experts, the sharp increase in demand for STEM training in the labor market will increase the creation of new jobs by more than $1 \mathrm{mln}^{10}$ (figure 3 ).

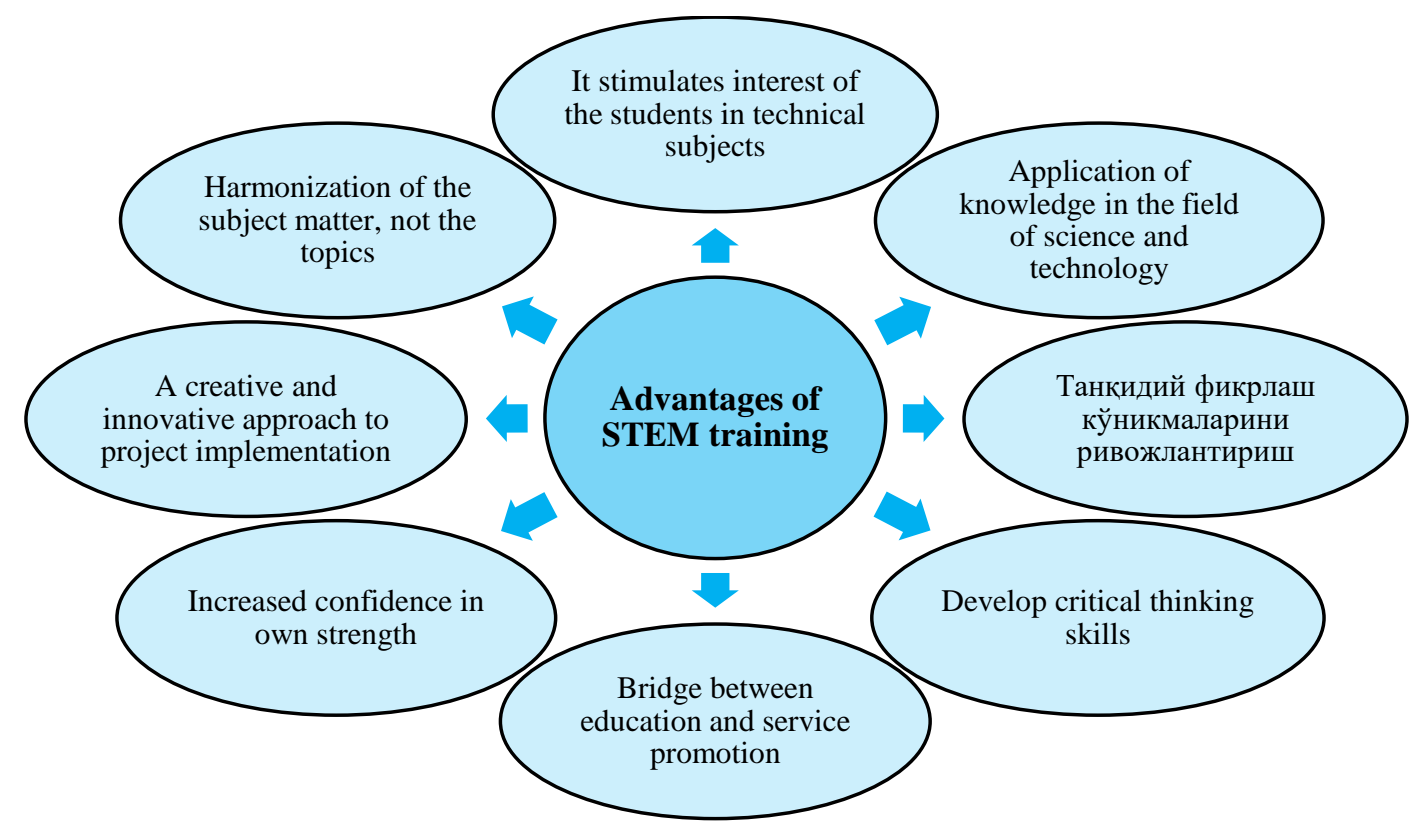

Figure 3. Advantages of STEM training

Austria, Germany, Greece, Ireland, Italy, Norway, Romania, Turkey and the United Kingdom participated in The INSTEM project which was organized by the EU during 2012-2015 years. As a result employment increased by $12 \%$ among the specialists trained in STEM education system. According to the labor market analysis, it is desirable to continue this project, because demand for STEMtrained specialists is expected to increase by $8 \%$ till $2025^{11}$.

The essence of the STEM education system is that in the case of reproductive teaching, students need to memorize and repeat the material mentioned in the textbooks by the instructor and in this innovative teaching methodology, first of all, students should be encouraged to think critically, approach unusually, format the ability to implement the acquired knowledge in practice. At the same time, four STEMeducators are taught separately, but not in isolation.

${ }^{10}$ Dugger W. E. Evolution of STEM in the United States // 6th Biennial International Conference on Technology Education Research, Gold Coast, Queensland, Australia. 2010. URL: http://www.iteea.org/Resources/PressRoom.
In order to develop the STEM education system in Uzbekistan, first of all, it is necessary to train teachers who can adopt this technique. It is desirable to develop developed countries` practice. For example, the program "100Kin10" is being implemented by the initiative of leading universities of the USA. The program envisages the training of 100,000 teachers for the STEM-education system by 2021 in the US. In the United States, more than 50,000 teachers have been trained for the STEM education system.

The STEM-training system in Singapore for the past five years has increased by $13.6 \%$. The doctorate dissertations that have been supported in this area over the last 10 years have tripled. the STEM-education system was adopted in $32 \%$ of higher education institutions and $68 \%$ of education centers in Australia. The salary of STEM-educators is considered as the highest one in the country ${ }^{12}$.

${ }^{11}$ G.Nogaybayeva. Development of STEM-education in the world and Kazakhstan // "Bilimdi el - Educated country", №20 (57) from October 25, 2016.

${ }^{12}$ Calof J., Smith J.E. Foresight impacts from around the world: a special issue // Foresight. 2012. Vol. 14, № 1. P. 5- 14. 


\begin{tabular}{|c|c|c|c|c|c|c|}
\hline \multirow{4}{*}{ Impact Factor: } & ISRA (India) & $=3.117$ & SIS (USA) & $=0.912$ & ICV (Poland) & $=6.630$ \\
\hline & ISI (Dubai, UAE & $=0.829$ & РИНЦ (Russia & $=\mathbf{0 . 1 5 6}$ & PIF (India) & $=1.940$ \\
\hline & GIF (Australia) & $=0.564$ & ESJI (KZ) & $=8.716$ & IBI (India) & $=4.260$ \\
\hline & JIF & $=1.500$ & SJIF (Morocco & $=5.667$ & OAJI (USA) & $=0.350$ \\
\hline
\end{tabular}

Summary.

The most important task of ensuring the employment of the population is the formation of a system of training creative personnel that meets the structural changes in the labor market. A creative worker for the innovation economy is a creative person who is capable of adopting unusual approach to problem solving, proposing new ideas and proving their practical value.

One of the primary goals of economic development in developed countries is to enrich human capital. Therefore, in order to train creative personnel for the modern innovation economy, it is proposed to increase the number of students in higher education institutions and to radically update students' teaching methods in the higher education system based on advanced international experience, ie introduction of a special STEM system. In order to increase the number of students in higher education institutions, special attention should be paid to the preparation of highly qualified specialists in the field of information technologies and communications, taking into account reforms in the field of "digital economy" in the country

Since the 11-year compulsory education system has been introduced at secondary schools, it is advisable to establish "Departmental" colleges of the relevant ministries and agencies and "Multi-band" vocational educational institutions on the basis of existing vocational colleges.

Experts who have experience and graduates should work together in order to develop their skills team working, along with the improvement of their skills directly at the workplace.

\section{References:}

1. (2017). The Decree of the President of the Republic of Uzbekistan "On the Strategy for the Further Development of the Republic of Uzbekistan" dated February 7, 2017 PF-4947 Decree No.

2. (2018). The decree of the President of the Republic of Uzbekistan from September 21, 2018 of N UP-5544 "About approval of strategy of innovative development of the Republic of Uzbekistan for 2019-2021".

3. (2017). Resolution of the President of the Republic of Uzbekistan "On measures for further development of the higher education system" from April 20, 2017, N PP-2909.

4. (2017). Application of the President of the Republic of Uzbekistan Shavkat Mirziyoev to the Oliy Majlis of December 23, 2017.

5. (2018, October 24). Needs for modern personell for a rapidly developing economy. UzA.

6. (n.d.). Statement by the President of the Republic of Uzbekistan at the solemn ceremony, dedicated to the 26th anniversary of adoption of the Constitution.

7. (2018). Decree of the President of the Republic of Uzbekistan Shavkat Mirziyayev to the Oliy Majlis of the Republic of Uzbekistan dated December 28, 2018.

8. Calof, J., Smith, J. E. (2012). Foresight: A special issue foresight. Vol. 14.
9. Gildons, M. (2008). Engineering by the numbers. Washington, DC: American Society for Engineering Edication.

10. Dugger, W. E. (2010). Evolution of STEM in the United States // 6th Biennial International Conference on Technology Education Research, Gold Coast, Queensland, Australia. Retrieved 2010, from: http://www.iteea.org/Resources/PressRoom/Au straliaPaper

11. Porter, M. E. (1998). Competitive Strategy: Techniques for Analyzing Industries and Competitors (2nd ed.). (p.397). New York: Free Press.

12. Gilford, J. (1965). Structural model of intelligence. Psychology of thinking. (p.244). Moscow.

13. (2015). UNESCO Indicator - Gross Entry Ratio to First Tertiary Programs. Retrieved 2019, from uis.unesco.org/index

14. Nogaybayeva, G. (2016, October 25). Development of STEM-education system in the Kazakhstan and in the world. Bilimdol ale Formed Country, №20 (57). 